\title{
Green Human Resource Management and Environmental Innovativeness
}

\author{
Sufaid $\mathrm{Ali}^{1}$, Anees Janee Ali ${ }^{1}$, Khurram Ashfaq ${ }^{2}$, Jamshed Khalid ${ }^{2 *}$ \\ ${ }^{1}$ School of Management, Universiti Sains Malaysia, Penang 11800, Malaysia \\ ${ }^{2}$ College of Commerce, Government College University Faisalabad, Faisalabad 38000, Pakistan
}

Corresponding Author Email: Jamshed.jt@gmail.com

https://doi.org/10.18280/ijsdp.160613

Received: 5 June 2021

Accepted: 1 September 2021

\section{Keywords:}

green human resource management, Green HRM, environmental innovativeness, innovative culture

\begin{abstract}
Drawing upon the resource-based view and the situated learning theory, this study examined the effect of green human resource management (HRM) practices on the firm environmental innovativeness. The moderating role of organizational innovative culture on the relationship between green HRM and firm environmental innovativeness was also assessed. A survey of 212 furniture manufacturing companies in Malaysia was analyzed using structural equation modeling. Results from the data analysis suggest that green HRM practices are positively associated with the firm environmental innovativeness. The positive effect of green training and green compensation on firm environmental innovativeness was found to be increased by moderating the role of organizational innovative culture. The present study clarifies key green HRM practices that can assist the environmental innovativeness in Malaysian furniture manufacturing firms and advances related research by proposing and examining an overarching model to enlighten such synergies and the moderating role of organizational innovative culture. The findings further extend the scope of green HRM research to promote innovation in the manufacturing firms. The theoretical and practical implications of green HRM are presented to enhance the environmental innovativeness.
\end{abstract}

\section{INTRODUCTION}

Firm environmental innovativeness has received significant attention, particularly, in the contemporary dynamic and competitive market. Organizations need to possess innovative capacities to continue facing increased competition and the rapidly changing environment. A new manifestation of innovation for organizations, which allows businesses to gain competitive advantage through innovative activities for themselves and society as a whole, is particularly necessary to meet environmental challenges [1]. For this sake, many organizations, who have committed to environmental policy in order to drive their businesses towards the undefined aim of sustainability, have adopted the mantra of sustainable growth. Accordingly, managers believe that environmental innovativeness is salient for corporate sustainability [2]. However, management cannot always be conscious of how new environmental concepts are promoted to help the organization meet sustainable environmental goals. Certainly, employees can deliver these innovative capacities, whether related to processes or products. Human resource management (HRM) is, therefore, central to the exertion of firm innovativeness [3].

The concept of "green" refers to pursue knowledge and practices that are supportive to more environment-friendly and ecologically responsible decisions as well as lifestyles, which would assist in protecting environmental sustainability along with the natural resources [4]. In this way, green management is responsible to ensure sustainable business without compromising the future need by reducing pollution and the amount of energy that is being consumed. By going on this part, green management can make a way for a cleaner and greener environment. The term Green HRM has now become the buzzing word in the business field and, over time, is becoming more and more vital. This term is also embraced in the emerging research on environment studies since the awareness of innovation and technological sustainability is growing worldwide [5]. At present, Green HRM is not only an issue of environmental awareness but also of the economic and social wellbeing of both the organization and its staff. In their study, Jabbour and de Sousa Jabbour [6] emphasized that Green HRM is related to the "systemic, planned alignment of typical human resource management practices with the organization's environmental goals" (p. 116). Simply put, as explained by Shen, Dumont and Deng [5], Green HRM can be defined as Green employees who understand, appreciate, and pursue Green initiatives in the HRM processes such as recruitment, selection, training, talent management, and compensation. Recent literature also supports the importance of Green HRM practices for firm innovation. For instance, Singh, Del Giudice, Chierici, and Graziano [7] directed a study on how green human resource management interacts with the ties between Green Transformational Leadership and Innovation, by considering resource-based views. Their study revealed that Green HRM practices circuitously influence innovativeness which stimulates the environment-related performance of the firm.

Malaysia has been considering one of South East Asia's most significant manufacturing economies over the past decade. The manufacturing sector contributed significantly to the country's economic growth after its transition from agricultural to industrial economies [8]. This transformation, 
however, caused some damaging effects on natural resources. Industrial production employed more natural resources and results in immense waste and environmental pollution. Consequently, the country is facing extreme pollution and depletion of natural resources. Industries' greenhouse gases (GHGs) can trigger major health issues, environmental catastrophes such as acid rain and flooding, food shortages, etc. due to its risk to national food security and export revenue from plantings. As identified by the Mokthsim and Salleh [9], air pollution, water pollution, and the disposal of solid waste are Malaysia's major environmental concerns.

The World Development Indicator data shows that the emissions of Malaysian carbon dioxide are continuing, with a huge spike at the beginning of the 90s industrial development [10]. The manufacturing sector in Malaysia, as with other emerging nations, is facing technological limitations to overcome these challenges [11]. Given this, it is of high importance for the manufacturing sector, particularly the furniture manufacturing firms, to reform their business models by incorporating both economical and environmental needs for the sustainability of the business. This concept encompasses not just a concern for the environment, but also the social and economic well-being of both the firm and its personnel. By establishing HR policies and practices, training individuals to become more environmentally aware, and enforcing environmental legislation, Green HRM plays a vital role in saving the environment. As found by some recent studies, organizations can affect their employees' pro-environmental behavior by implementing green HRM practices $[12,13]$.

A critical look at the furniture manufacturing sector in Malaysia is contemplating policies for firm environmental innovativeness. The two-digit golden years of furniture industry growth in Malaysia coincided with the 1st and 2nd Industrial Masters Plan in the 20-year period of 1986-2005. However, the growth rate has fallen from 2006 to 2018 , averaging 2 percent every year, showing a loss of competitiveness for the large production bases in Vietnam and China [14, 15]. Previously, Ratnasingam [14], and Ng and Thiruchelvam [16] studies acknowledged the core challenges to long-term furniture industry growth and competitiveness due to lack of innovation. Whether the factors that hinder the long-term growth of the Malaysian furniture sector or other supportive factors, like the degree of automation or technology application, require further research.

A recent study led by Ratnasingam [15] emphasizes the fact that Industry 3.0, which precedes the fourth industrial revolution, has relatively low dissemination in the furniture sector in Malaysia and can severely hamper the move forward to Industry 4.0. Their findings further exposed that there is relatively little willingness to adopt Industry 4.0 in the manufacture of furniture because almost $96 \%$ of respondents were not aware of product innovation, lack of networking infrastructure for IT, and data-management inside firms' production facilities. Additionally, Ratnasingam [14] concluded that higher initial investments necessary are likely to sadden most furniture manufacturers regarding the advantages of automation or innovation at the workplace. Given this, the leading issue for the furniture industry is to enhance their capabilities and competitiveness from the perspective of the environmental innovativeness of furniture firms. Malaysian furniture manufacturing firms can be trendsetters in the region by adopting new green policies and practices in HRM and embrace a culture of innovation within the organization.
The negative environmental impacts may be minimized by environmental policies incorporated in organizational roles and procedures, industrial innovation, and enhanced environmental management systems (EMSs). At an organizational level, it is also possible to deal with such concerns by shifting human capital criteria and integrating them into activities of human resources management (HRM) which are in line with the environmental policy. Some previous studies attempt to investigate the environmental performance of the furniture industry by using different measures [17]. Nonetheless, there is a lack of research exploring the link between Green HRM practices and firm environmental innovativeness in Malaysian furniture manufacturing. This evident a knowledge gap to be filled through empirical investigation. The present study, thus, is an effort in fulfilling this gap by determining the relationship between Green HRM practices such as green recruitment and selection, green training, green compensation, green performance assessment, and firm environmental innovativeness of furniture manufacturing firms of Malaysia. Principally, this study aimed to answer the following questions.

RQ (1). Do the Green HRM practices be accommodating in increasing environmental innovativeness in Malaysian furniture manufacturing firms?

RQ (2). Does innovative organizational culture moderate the relationship between 'Green recruitment and selection', 'Green training', 'Green compensation', 'Green performance assessment', and 'firm environmental innovativeness'?

This study will contribute to advance Green HRM practices and their link to firm environmental innovativeness in response to society as well stakeholders' call for environmental safety. This study will be helpful in advancing the theoretical lenses of both the resource-based theory and social learning theory in the context of Malaysian manufacturing firms on how Green HRM practices lead to firm innovativeness. Moreover, this study proposed that if an organization encourages innovative culture, the Green HRM practices would be more effective in promoting innovativeness. This study believes that resource-based theory provides a guiding paradigm in understanding, predicting, and controlling human resources in a firm while social learning theory conceptualizes that developing an effective innovation culture constantly encouraged the employees to adopt new technologies that result in high environmental innovativeness for an organization. The study will develop new grounds for further research by empirically investigating the moderating role of innovative organizational culture on the relationship between Green HRM practices and firm environmental innovativeness.

\section{THEORY AND LITERATURE REVIEW}

Green human resource management (HRM) and its association with environmental concerns have in recent years attracted much attention from academic researchers and practitioners all over the world. Exploring and synthesizing green HRM practices would enhance the readers' understanding of fundamental environmental issues. Following the description of underpinning theories, a 
discussion on environmental innovativeness, green HRM practices, and organizational innovative culture is offered.

\subsection{Green HRM theories}

The researchers attempted to explore the green HRM practices by applying numerous theoretical approaches. The most widely used theories for green HRM are AMO theory, social, identity theory, institutional theory, RBV theory, and social learning theory. From the lens of AMO theory, performance is a result of the interaction of employees' capacity to perform (ability), willingness to perform (motivation), and opportunity to perform through participation (opportunity).

The social identity theory, on the other hand, posits that subjects develop their sense of who they are based on their belongingness to some specific groups, such as age group and gender organizational membership [18]. Given this, it can be said that that employee who adopts and develop a green identity at work will support environmentally concerned behaviors which finally leads to better environmental performance. While institutional theory proposes that external pressures shape organizational actions. Its application to the natural environment, several institutional research have highlighted the effects of coercion from regulatory and social pressures and how they encourage homogeneous outcomes [19]. Resource-Based Theory (RBV) indicates that specialized non-replicable resources produce opportunities for heterogeneity leading to competitive advantage [20]. This theory is more appropriate as it implies that green outcomes of the workforce are critical from the internal perspective. the RBV states that resources that are valuable, rare, inimitable, and imperfectly substitutable are the main source of an organization's competitive advantage $[20,21]$. Based on this conception, this study employed that the green behavior of employees is the main resource that contribute to the environmental innovativeness of a firm.

\subsubsection{Resource-Based View Theory (RBV)}

The relation between human capital and a firm's success, productivity, and creativity are not new and are focused on emerging HRM and Strategy literature [21, 22]. The firm's resource-based views (RBV) show that competitive advantages and success rely on how companies utilize their important, rare, and hard-to-imitate strategic resources in a market environment [21]. Moreover, when the vital resources are precious and costly for the rivals to reproduce or replace them, the firm can sustain superior success and competitive advantage by utilizing its resources.

While applying RBV to the HRM-innovative relation, prior literature considered that managers and employees constitute critical resources like any other business, the main aim of which is to create, encourage, and give opportunities for high job behavior for environmental innovation [23]. Several previous authors suggested that human resources meet the above RBV requirements for creating and promoting increased environmental creativity because human capital is habitually embedded in the multi-faceted welfare structures of companies and makes human capital sufficiently useful for a specific business as for its competitors in the markets [22].

The RBV transforms human capital into the strategic advantage of companies through imaginative and inventive behavior. It stresses the role of human capital in establishing direct and efficient ties with the internal and external stakeholders of an organization [23]. Environmental policies are not likely to be achieved by organizations lacking the essential competencies of human capital. Thus, according to the resource-based view, green outcomes of the workforce are critical from the internal perspective. Hence, this study underpins the theme of outcomes of Green HRM in the light of resource-based theory from the internal viewpoint. Moreover, the RBV states that resources that are valuable, rare, inimitable, and imperfectly substitutable are the focal source of an organization's environmental innovativeness [20,21].

Several authors have applied the RBV to the field of HRM $[24,25]$, but still, only a few who tested it in the field of Green HRM. The authors who applied in strategic HRM suggest that the knowledge, skills, and activities of the workforce are core resources that contribute to the firm's competitive advantage. In the same way, this study conceptualizes that green recruitment and selection, green training, green compensation, and green performance assessment are the primary resources that are supportive for the firm's environmental innovativeness. The significance of Green HRM in accomplishing the environmental innovativeness goal of an organization has received substantial attention in the RBV literature. As described by and Chesbrough, Lettl, and Ritter [26], the way a firm's resources are created and deployed within organizations depends on the way in which they are generated by the use of resources. Thus, in the context of Green HRM, different green practices are needed in order to create environmental innovation through human capital development.

\subsubsection{Social Learning Theory (SLT)}

Social learning theory indicated that an individual can learn in his or her social environment. The observation and imitation of other people may also ascertain new abilities and behavior [27]. Thus, the social interactions will spread awareness and knowledge among employees. People may informally learn from their colleagues with environmental expertise in contexts with a positive culture even in the context of diversity [28]. Jackson and Seo [29] stressed the importance of experiential organizational activities that foster a creative approach of environmental awareness by understanding the human behaviors. Organizations such as Google and Intel for instance have developed employee gardening facilities where workers can contribute to the cultivation of the gardens and even organic vegetables later in the restaurants and cafeterias of companies. These campaigns and activities can be implemented for educational purposes so that staff can informally learn about the importance of environmental sustainability.

The theory of social learning illustrates the critical need to observe and model the actions, behaviors, and emotional responses of people. This theory is attributed to learning with a focus on modeling and observing. The theory was initially derived from behavioralist, and today some concepts of cognitivism have also emerged with its conceptualization, which gave it a new name such as "social cognitive learning" [30]. The theory of social learning also contributes to cognitive and environmental factors which intervene to influence human behavior and learning. They assumed that people learn from each other, inclusive of ideas such as observational learning, simulation, and modeling [31].

The social theory describes how human behavior interacts constantly between the cognitive, behavioral, and environmental factors. Innovation is also regarded as a 
complex social learning process; workers constantly consume information and skills in the workplace. This signifies the HRM practices at workplace are helpful in implementing innovative organizational strategy by altering the employee's behavior. Innovations in the production of goods as well the procedures have continuously disrupted organizational growth. According to Akers and Jennings [27], organizations gain innovative competitiveness through the creative behaviors of employees. Combinations of various organizational resources in an organization can be considered as a part of creativity.

The firms are, hence, must consider the green HRM practices and promote it as a social learning process to upsurge the overall environmental innovativeness of a firm. As to implement Green HRM to promote environmental innovativeness, the social learning process will assist in encouraging green behaviors and awareness among employees.

\subsection{Firm environmental innovativeness}

Studies in the field of economics, organizational management, strategic management as well as marketing have shown that innovativeness is a significant driver for economic development. Several scholars have argued that it is a process by which organizations can use their core skills and transform them into products and services vital to the overall success of a firm. Although innovation is widely viewed as an integral consideration of competitiveness, integrated into organizational structures, procedures, products, and services in a business, previous studies have concentrated on the environmental dimension of innovation in an organization [32, 33].

According to Angelo, Jabbour and Galina [34], firm environmental innovativeness can be defined as the "organizational implementations and changes focusing on the environment, with implications for companies' products, manufacturing processes, and marketing, with different degrees of novelty". Environmental innovativeness is a strong instrument to undermine existing industries and established companies that need to stay competitive in dynamic markets by new firms. The policymakers may use environmental and policy-making initiatives to simulate Eco-innovation, thereby minimizing emissions and general natural resources depletion, as well as stimulating research and development [35]. Environmental innovativeness can be referred to as "the production, assimilation or exploitation of a product, production process, service or management or business method that is novel to the firm [or organization] and which results, throughout its life cycle, in a reduction of environmental risk, pollution and other negative impacts of resources use (including energy use) compared to relevant alternatives" [36].

Earlier research on environmental innovation from the RBV perspectives argued that innovation tools enable innovative enterprises to differentiate themselves from nonenvironmentally innovative firms [35]. The present environmental condition (e.g., complexity, high risk, and fluctuations) implies that companies must cultivate innovation such that their competitiveness is sustained or enhanced. The potential of innovativeness is one of the most important factors impacting the environmental success of any firm [34, 35]. Bocken and Geradts [37] argued that innovativeness provides flexibility to the organization in satisfying the needs of consumers and society. For contemporary manufacturing organizations in emerging economies, it has been considering a major goal for environmental sustainability.

The innovativeness within a firm includes the organization's human capital and its capacities to embark on creativity. One of the most critical avenues for the generation of new and creative ideas is the collective insights of all employees together. Often, employees of an organization are marked as the most knowledgeable innovation source due to their expertise and awareness of the market and industry. They can have comprehensive and insightful perspectives on emerging products and services. Environmental innovativeness means novelty and creativity in the system and process to make the production procedure more effective and less harmful to the environment. However, these goals are achievable only when the whole organizational resources, particularly human capital resources, are implied to innovation within the production process and system [37]. Hence, efficient employees are much needed who are mindful and firm commitment to follow environmental sustainability rules and regulations. Additionally, it is also suggested by researchers that Green HRM practices such as green recruitment, green training, green compensation, and green performance appraisal are imperative to accomplish environmental innovativeness in a firm [38, 39]. Moreover, some researchers argued that Green HRM practices facilitate the adoption and implementation of environmental technologies [40]. This study considers different green HRM practices to determine the environmental innovativeness among furniture manufacturing firms in Malaysia.

\subsection{Green HRM practices}

The prior literature on Green HRM attempted its effect and relationship to the environment-related characteristics [41], stakeholder pressure [38], corporate social responsibility [42, 43], resistance to change [44], and strategic HR competencies [45]. The term 'Green' applies to practices that make the use of energy more effective and minimize the environmental damage compared. It's always used in a discussion now for almost all the environmental impacts and advantages.

The 21 st century is regarded as the century of multicultural and diverse emerging markets, which are scattered across the world [7]. For several reasons, Green HRM has now become a necessity in organizations. One of them is the several harmful environmental occurrences. Secondly, production firms use natural resources to manufacture materials or products, often contributing to industrial waste and environmental contamination. Third, the by-products of unsustainable use of natural resources that supply raw materials are deforestation, ecological instabilities, and global warming [46]. Hence, manufacturing firms need to take initiatives with a focus on environment-friendly products and services. For this sake, the HRM department of an organization can play a vital role.

Previous scholars have argued that a spectrum that encompasses all practices - role analysis, job requirements, recruitment and selection, training and growth, success and evaluation, and incentives - is frequently studied in terms of how HRM can be greened [47]. As mentioned by Renwick et al. [48], the recent studies are exploring green HR structures and individual workers' conduct, multi-level dynamism, and new theoretical direction. Green HRM has been presented and enhanced in many ways in past research, including Green HR 
procedures, large contextual problems, and the performance impact of Green HRM.

The key important practices emphasized by most of the previous authors are green recruitment and selection, green training, green compensation, and green performance assessment [7, 43, 49, 50]. As defined by Kim et al. [49], green recruitment and selection the integration of environmental management with recruitment \& selection, where HRM policies are used to promote environmental sustainability and the wise and judicious use (conservation) of resources within business organizations. Green training on the other hand refers to the "development of educating employees about the value of environmental management, train them in working methods that conserve energy, reduce waste, diffuse environmental awareness within the organization, and provide the opportunity to engage employees in environmental problemsolving" [51]. Luu [50] defined green compensation as the recognition of the contribution of employees in the creation of a more sustainable company. It is the result of the success of employees in their ecological performance appraisal and the proof that a company's strategic sustainability goals are being mirrored and accomplished from the top to the bottom. While the green performance assessment can be defined as the process by which employees are prompted to enhance their professional skills that help to achieve the organizational goals and objectives in a better way.

General activities of HRM were integrated with green aspects; thus, in each HRM procedure, in order to prevent misunderstanding, the word 'Green' was introduced [51]. The point is that Green HRM has a central position and allows other mechanisms to sustain the competitive advantage in several different ways [6]. For example, in a study conducted by El-Kassar and Singh [52], the direct influence of environmental performance on competitive edge for companies with lower human resources practice was found to be more significant. Furthermore, the findings show that companies with proven HR practices have a more integrated competitive advantage by incorporating better environmental innovation and business efficiency. Based on the evidence from most past studies, Green HRM practices can be seen as predictors of innovation, especially for the furniture manufacturing industry. However, Seeck and Diehl [53] offered a literature review where he found that HRM has not significantly affected administrative or process innovation in relation to the product and technical innovation.

As described above, previous researchers found mixed results on the relation between HRM and innovation within an organization. Moreover, there are limited empirical studies that confirmed the relationship between Green HRM and firm innovativeness; thus, an indication of these relationships seems to be unsettled and demanding further investigation. In addition, Malaysia is an emerging economy, the green problem has become more prominent. One explanation is that these emerging economies in recent years have started to utilize more natural resources and energy, and thus led to the deterioration of the environment [50]. Thus, it seems important to provoke Green HRM practices in Malaysia, particularly in the furniture manufacturing industry.

\subsection{Role of organizational innovative culture}

A multitude of phenomena is explained by several different scholars using the term "culture". Since each person appears to take a slightly dissimilar approach, no widely agreed concept exists [54]. Ott [55] has described over 70 terms or phrases in this regard that were used to characterize corporate culture. Similarly, Parker [56] argued that corporate culture is the usual and conventional way of doing things, which all members share to a greater or lesser extent, and which the new members must learn and at least embrace in part to carry on the service of the company. Alvesson [57] concentrated on culture itself rather than its consequences and described it as philosophies, beliefs, and profound values which exist in all companies and recommend how people can function in them. On the other hand, culture was regarded by Peters and Waterman [58] by symbolic means as a predominant and consistent collection of shared beliefs, including tradition, history, legend, slogan, fairy tales, and anecdotes.

It is highly significant that creativity is practiced within an organization. An innovating corporate culture is one that encourages workers to be creative. In this sense, Lau and $\mathrm{Ngo}$ [59], who perceived this issue from internal adjustment and integration, noted organizational culture as a model of fundamental assumptions - conceived, found, or created by a particular community. Such a pattern performed well enough to be valued and to be demonstrated to new participants as the right way to view, think and experience these issues. In the same way, Wiener [60] argued that "most researchers of organizational culture agree that shared values are a key element in the definition of culture".

Research by Lukoto and Chan [61] has shown workers are likely to exhibit innovative behavior, in particular phases of innovative working environments, when they experience a positive, innovative community at the workplace. These phases include exploring possibilities, developing ideas, encouraging ideas, and producing ideas. There is also a lack of empirical studies into the corporate culture on different dimensions of creativity. Quite a few studies over the years have examined certain aspects of this issue [62-64]. The results of the study of Prajogo and McDermott [65] showed that an organization can harmonize various types of culture. The creative culture of a company needs to be strengthened to ensure that all of its employees pursue their critical role in new goods, services, or processes.

In order to increase its innovation potential, a company must recognize that a significant concentration of innovative culture within the organization is necessary [66]. Some researchers described that transfer to a new company, product or service can be focused on the knowledge of the various knowledge, technology, institutional learning process and core business of the business the efficiencies and collaborations between [54, 67]. An innovative culture acts as a major influence on the conduct of employees and promotes initiative, not conformity and reliance. Innovative cultural organizations also employ systems that are organic and versatile, requiring workers to retain open contact and constantly refresh their expertise in the field. Hence, an innovative culture is undeniably apt for an organization that has an aim for amplified environmental innovativeness.

\subsection{Summarized reflections on literature review}

Exploring and synthesizing the prior literature on green HRM practices clearly indicated that there is an association between different green HRM practices and environmental innovativeness. The recent literature suggests there is still lack of empirical research on this emerging field. By exploring the effect of green HRM and how it contributes to the 
environmental policy of manufacturing firms in developing nation will cover the knowledge gap and offer valuable insights. It would be interesting to uncover the relationship between different green HRM practices and environmental innovativeness of the firms. Secondly, by investigating the role of organizational innovative culture as moderator will also appropriate to advance the study of the relationships between green HRM and environmental innovativeness. Strengthen the theoretical foundations of green HRM and innovation, this study can offer interesting future lines of research.

\section{RESEARCH HYPOTHESIS AND DEVELOPMENT}

Several previous authors proposed to consider the significant role of internal resources, in particular human resources and employees' capabilities [52] in developing a firm's environmental performance. HRM has been a vital force in addressing cognitive and environment-related innovation since the mid-1990s. In a study conducted by Renwick et al. [51], the findings confirmed that different practices by HR have a positive link to organizational environmental innovation. Among those practices, most prominent are green recruiting, for example, (i.e., employing workers with unique environmental expertise and general environmental sensitivity), green training and engagement (i.e., improving environmental skills and employee participation in green behavior), green performance appraisal, and green rewards (i.e., assessing employee performance by taking green actions into account).

This section aims to present the theoretical framework, in accordance with the debate in previous sessions. As shown in Figure 1, the framework comprises six constructs. The independent variables include green recruitment and selection, green training, green compensation, and green performance assessment. The dependent variable is firm innovativeness. This study assumes that all green HRM practices have a positive effect on the firm environmental innovativeness of Malaysian furniture manufacturing firms in Malaysia.

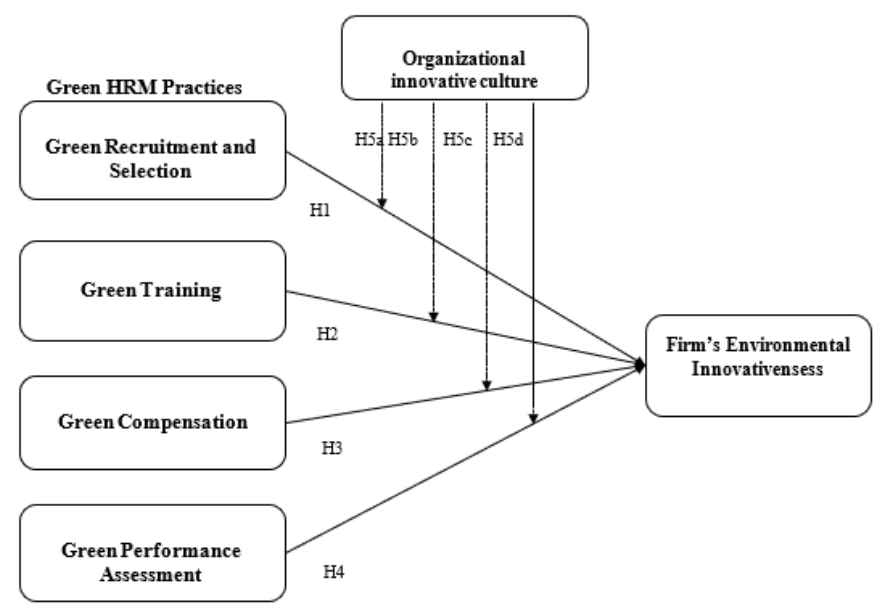

Figure 1. Research framework

H1. Green recruitment and selection have a positive effect on the firm's environmental innovativeness.

H2. Green training has a positive effect on the firm's environmental innovativeness.

H3. Green compensation has a positive effect on firm environmental innovativeness.
H4. Green performance assessment has a positive effect on firm innovativeness.

H5a: Innovative organizational culture significantly moderates the relationship between Green recruitment and selection and firms' environmental innovativeness.

H5b: Innovative organizational culture significantly moderates the relationship between Green training and firms' environmental innovativeness.

H5c: Innovative organizational culture significantly moderates the relationship between Green compensation and firms' environmental innovativeness.

H5d: Innovative organizational culture significantly moderates the relationship between Green performance assessment and firms' environmental innovativeness.

\section{RESEARCH METHOD}

\subsection{Sample and data collection}

The companies' list is obtained from the Malaysian Timber Industry Board (MTIB). The furniture manufacturing sector is known for being a major source of waste, water pollution, air pollution. Moreover, this sector is considered as an overconsumer of natural resources as well as a clear contributor to climate change. Due to this, these manufacturing firms represent an appropriate population for present research on Green HRM, innovative organizational culture, and environmental innovativeness.

There are 1890 total registered furniture SMEs in Malaysia [68]. However, as the literature suggested, small companies are less involved in practicing the Green HRM, hence, the present study targeted medium and large companies. The medium and large Malaysian furniture companies are 983 $(52 \%)$ of the total furniture SMEs. In each randomly selected furniture manufacturing firm, a key informant was identified and contacted via telephone and email in order to acquire their preliminary consent for participation. The unit of analysis for this research is organization.

The measurement constructs adopted in this study have been validated in prior research. This study utilized a simple random sampling technique for data collection. The pre-test was performed by five individuals (two academicians and three HR managers with extensive industry experiences) to establish the construct validity. The survey questionnaire measured Green HRM and firm environmental innovativeness. A total of 650 questionnaires were dispersed to managers at each company. At first, there was no response was received from most of the managers in target companies. One phone and two email reminders were sent every two weeks. This achieved a total of 221 questionnaires that were returned, with none of them were not appropriately filled. Thus, 212 questionnaires were considered for further analysis.

As shown in Table 1, the majority of the respondents were male (53.3\%), married (72.6\%), and age group 31-40 (40.5\%). Most of the respondents were managers (30.2\%) with a Master's degree (42\%) and having experience of 10 years or above $(33 \%)$.

\section{Questionnaire development}

The questionnaire was constructed by using items adapted from a variety of prior studies. For instance, green recruitment and selection were measured using six items [69], green training with five items [70], green compensation with four 
items [69], and green performance assessment with five items [70]. In addition, firm environmental innovativeness was measured via five items adapted from Martinez-Conesa et al. [71].

Table 1. Demographic characteristics of respondents $(n=212)$

\begin{tabular}{lccc}
\hline Variable & Category & Frequency & Percent \\
\hline Gender & Male & 113 & 53.3 \\
Marital Status & Female & 99 & 46.7 \\
Married & 154 & 72.6 \\
Age & Unmarried & 56 & 26.4 \\
& & & \\
& 20 to 30 & 68 & 35.4 \\
$31-40$ & 86 & 40.5 \\
41-50 & 58 & 27.4 \\
Job Experience & 1 or above & 8 & 3.77 \\
1 to 3 years & 44 & 20.8 \\
4 to 6 year & 57 & 26.9 \\
7 to 9 year & 40 & 18.9 \\
10 or above & 70 & 33 \\
Current Position & & \\
Director & 20 & 9.4 \\
Manager & 64 & 30.2 \\
Executive & 91 & 42.9 \\
Senior & 37 & 17.5 \\
Diploma & 30 & 14.2 \\
Bachelors & 85 & 40.1 \\
Master & 89 & 42 \\
Doctorate & 8 & 3.8 \\
\hline
\end{tabular}

\subsection{Common method bias}

There could be possibilities of common method bias (CMB) in the data as all the exogenous and endogenous variables were collected at the same time from the same respondents. For this, as recommended by Podsakoff and Organ [72], Herman's single-factor method was employed that computed the CMB value. In Herman's single-factor method, the total variance value must be below 50\%. For the current research, an unrotated principal component factor analysis on all measurement items has been conducted, extracted four factors with eigenvalues greater than 1.0, which made up $68.83 \%$ of the total variance. As a result, it was noticed that factor one reported only $40.83 \%$ of the variance, hence it is confirmed that the common method variance is not a significant issue for the current study.

\subsection{Reliability and validity analysis}

The study carried out construct validity (also known as measurement validity) to investigate the measuring degree relevant to a theory or conceptual model [70]. In this study, two measurement validity components have been tested; convergent validity as well as discriminant validity. Table 2 presents the outer loadings and the AVE for endogenous variables and exogenous variables. The AVE exceeds the suggested value of 0.5 for all latent variables [70]. Thus, it is clear that the variance from the loading items was more than half the variance observed.

The convergent validity of the model was initially analyzed with indicator loading, extracted average variance (AVE), and composite reliability (CR). Table 2 shows the indicator loading for all items above the recommended value of 0.508 as indicated by Hair Jr et al. [73]. However, one item FEI6, GPA5, GT6 were deleted with factor loading less than 0.50 because the AVE for this item's latent variable was not more than the recommended value of 0.50 . Other than that, the AVE of all variables was in the range of 0.673 to 0.896 , higher than the recommended value of 0.50 . On the other hand, CR ranges from 0.855 to 0.958 , which is greater than the recommended value of 0.70 given by Hair Jr et al. [73]. This study, therefore, ensured that convergent validity appropriately existed.

The Heterotrait-Monotrait ratio (HTMT) method was applied to test the discriminant validity of the model as well. The study used the 0.90 criterion (i.e., HTMT.90) for establishing the discriminant validity for the study's model. Figure 2 represents the ratio of Heterotrait-Monotrait of the constructs. The discriminating validity of the model has been demonstrated in Table 3 the HTMT.90 results confirmed that all the criteria were not more than the critical value of 0.90 . Thus, there was adequate convergent and discriminant validity in the measurement model.

Table 2. The results of measurement model

\begin{tabular}{|c|c|c|c|c|c|}
\hline Variable & Item & Loading & Cronbach's Alpha & $\mathbf{C R}$ & AVE \\
\hline \multirow[t]{5}{*}{ FEI } & FEI1 & 0.815 & 0.863 & 0.902 & 0.65 \\
\hline & FEI2 & 0.782 & & & \\
\hline & FEI3 & 0.858 & & & \\
\hline & FEI4 & 0.89 & & & \\
\hline & FEI5 & 0.669 & & & \\
\hline \multirow[t]{6}{*}{ GC } & GC1 & 0.914 & 0.945 & 0.956 & 0.785 \\
\hline & $\mathrm{GC} 2$ & 0.886 & & & \\
\hline & GC3 & 0.884 & & & \\
\hline & GC4 & 0.9 & & & \\
\hline & GC5 & 0.855 & & & \\
\hline & GC6 & 0.875 & & & \\
\hline \multirow[t]{5}{*}{ GPA } & GPA1 & 0.583 & 0.76 & 0.837 & 0.511 \\
\hline & GPA2 & 0.842 & & & \\
\hline & GPA3 & 0.789 & & & \\
\hline & GPA4 & 0.696 & & & \\
\hline & GPA6 & 0.63 & & & \\
\hline \multirow[t]{4}{*}{ GRS } & GRS1 & 0.835 & 0.852 & 0.89 & 0.576 \\
\hline & GRS2 & 0.705 & & & \\
\hline & GRS3 & 0.773 & & & \\
\hline & GRS4 & 0.761 & & & \\
\hline
\end{tabular}




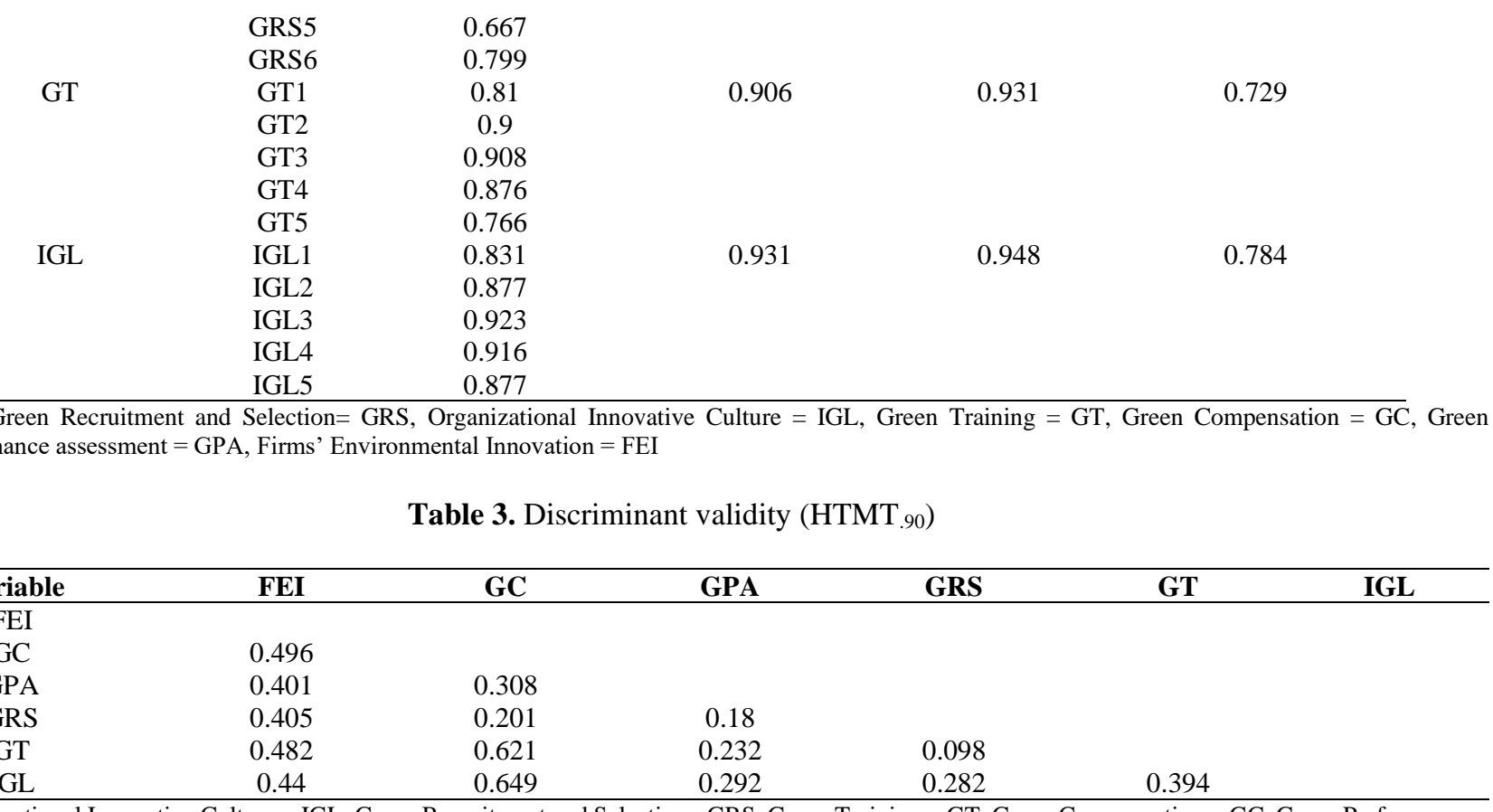

Note: Organizational Innovative Culture $=$ IGL, Green Recruitment and Selection= GRS, Green Training $=$ GT, Green Compensation $=$ GC, Green Performance assessment $=$ GPA, Firms' Environmental Innovation $=$ FEI

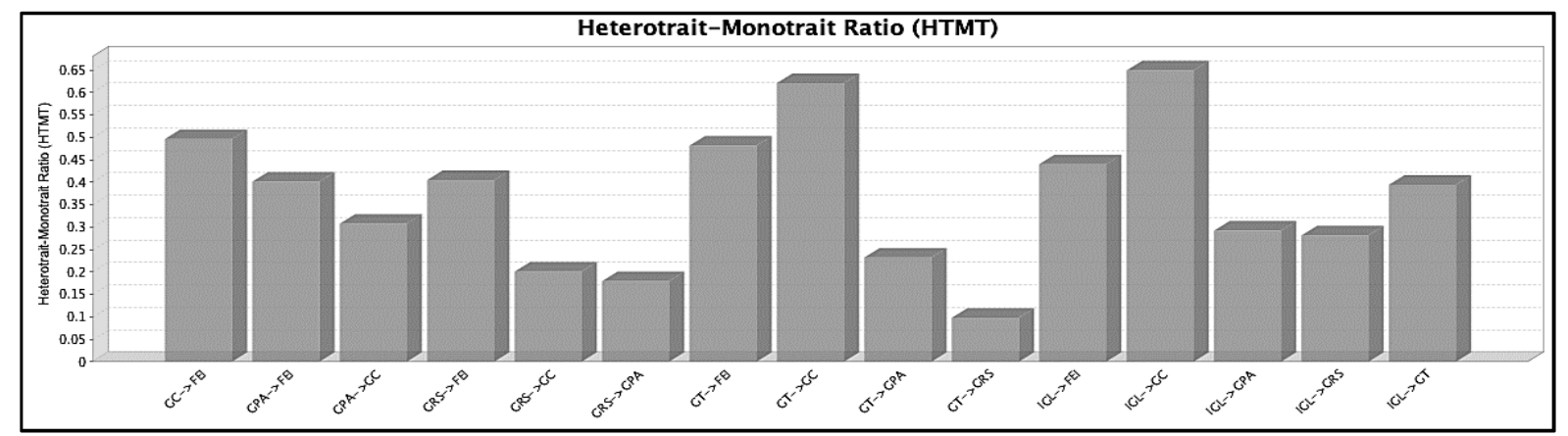

Figure 2. HTMT

\section{DATA ANALYSIS AND RESULTS}

\subsection{Hypothesis testing}

The structural model assessment was done in order to examine the defined relationships hypothesized in the research model. The variance inflation factors (VIFs) and tolerance techniques were applied at the first stage to assess the structural model for the sake of collinearity issues. Multiple regression variables are characterized by multicollinearity and measured by the variance inflation factor (VIF). In statistics, the VIF for a regression model variable is equal to the ratio of the overall model variance to the variance of a model that includes only that single independent variable. A high VIF indicates that the associated independent variable is highly collinear with the other variables in the model. The VIF and tolerance values of the constructs are shown in Table 4.

The next step in the research model is to evaluate the structural model through the use of the path coefficient. The significance of the path coefficient has been observed through a comparison between the $\mathrm{t}$-values and critical $\mathrm{t}$-values for significance levels of $0.01,0.05$, and 0.10 respectively [73]. Moreover, following the path coefficient, bootstrapping techniques were applied to calculate the empirical t-value for the significance of path coefficients using 1000 subsamples
[73]. The path coefficients attained through analysis to measure the statistical significance in the structural model have been shown in Table 5 .

Table 4. VIFs for collinearity evaluation of the structural model

\begin{tabular}{ccc}
\hline Constructs & VIF & Tolerance \\
\hline GC & 2.119 & 0.472 \\
GPA & 1.106 & 0.904 \\
GRS & 1.090 & 0.917 \\
GT & 1.510 & 0.662 \\
IGL & 1.681 & 0.595 \\
\hline
\end{tabular}

Note: Organizational Innovative Culture $=$ IGL, Green Recruitment and Selection $=$ GRS, Green Training $=$ GT, Green Compensation $=$ GC, Green Performance assessment $=$ GPA, Firms' Environmental Innovation $=$ FEI

To evaluate the moderating effect of Organizational Innovative Culture between independent variables (Green Recruitment and Selection, Green Training, Green Compensation, Green Performance assessment) and Firms' Environmental Innovation, the method of commodity indicators was applied. Interaction concepts were generated by different variables and moderators and were orthogonalized in order to minimize multi-coordination prior to analysis. Table 6 present the results of moderation analysis. Based on the 
moderation analysis results, it was found that organizational Innovative Culture moderates the relationship between GT and FEI, and GC and FEI. H6 and H7 were found significant. However, H5 and H8 were rejected.

\subsection{Predictive relevance and effect size}

Stone-Geisser's $\mathrm{Q}^{2}$ value may also be employed while determining the predictive relevance of the model. If $\mathrm{Q}^{2}$ is higher than zero, the model accurately predicts the endogenous constructions' data points [73]. For the sake of obtaining $\mathrm{Q}^{2}$, the blindfolding technique was performed through Smart-PLS. The blindfolding technique has been used by omitting every sixth data point in the endogenous construct's indicators as well as performing construct cross-validated redundancy. Then In smart PLS, the omitted data points have been treated as missing data. For calculating $\mathrm{Q}^{2}$, the difference between the omitted and predicted data points has been used. (Hair et al., 2014). $Q^{2}$ values of the model are displayed in Table 7.

The effect sizes of the study's constructs were also estimated. According to Sullivan and Feinn [74], the results of the study should disclose both the statistical significance (Pvalue) as well as the substantive significance. In this context, Hair et al. [73] recommended that change in $\mathrm{R}^{2}$ needs to be assessed when an exogenous variable is omitted from the model to calculate the effect size $\left(\mathrm{f}^{2}\right)$ that presents the substantive effect of the omitted variable on endogenous variables. Cohen [75] offered the common guidelines for the effect size such as $0.02,0.15$, and 0.35 for small, medium, and large effects respectively. The effect size of all exogenous variables is represented in Table 8

Table 5. Results of structural model analysis (direct hypothesis)

\begin{tabular}{ccccccccc}
\hline Hypothesis & Path & Beta & STD Error & T Values & P Values & $\mathbf{5 . 0 0 \%}$ & $\mathbf{9 5 . 0 0 \%}$ & Decision \\
\hline H1 & GRS -> FEI & 0.279 & 0.058 & 4.772 & 0.000 & 0.186 & 0.384 & Accepted \\
H2 & GT -> FEI & 0.267 & 0.059 & 4.517 & 0.000 & 0.170 & 0.367 & Accepted \\
H3 & GC -> FEI & 0.195 & 0.068 & 2.861 & 0.002 & 0.079 & 0.309 & Accepted \\
H4 & GPA -> FEI & 0.201 & 0.052 & 3.882 & 0.000 & 0.132 & 0.302 & Accepted \\
\hline
\end{tabular}

Note: Organizational Innovative Culture = IGL, Green Recruitment and Selection= GRS, Green Training = GT, Green Compensation $=$ GC, Green Performance assessment $=$ GPA, Firms' Environmental Innovation $=$ FEI

Table 6. Results of moderation analysis

\begin{tabular}{ccccccc}
\hline Hypothesis & Path & Beta & STD Error & T Values & P Values & Decision \\
\hline H5 & GRS*IGL -> FEI & 0.009 & 0.049 & 0.178 & 0.429 & Rejected \\
H6 & GT*IGL -> FEI & 0.133 & 0.056 & 2.394 & 0.009 & Accepted \\
H7 & GC*IGL -> FEI & 0.143 & 0.057 & 2.49 & 0.007 & Accepted \\
H8 & GPA*IGL -> FEI & 0.035 & 0.051 & 0.681 & 0.248 & Rejected \\
\hline
\end{tabular}

Note: Organizational Innovative Culture $=$ IGL, Green Recruitment and Selection= GRS, Green Training = GT, Green Compensation $=$ GC, Green Performance assessment = GPA, Firms' Environmental Innovation = FEI

Table 7. Predictive relevance $\left(\mathrm{Q}^{2}\right)$

\begin{tabular}{cccc}
\hline Constructs & SSO & SSE & $\mathbf{Q}^{\mathbf{2}}(=\mathbf{1 - S S E} / \mathbf{S S O})$ \\
\hline FEI & $1,060.00$ & 820.797 & 0.226 \\
GC & $1,272.00$ & $1,272.00$ & \\
GPA & $1,060.00$ & $1,060.00$ & \\
GRS & $1,272.00$ & $1,272.00$ & \\
GT & $1,060.00$ & $1,060.00$ & \\
\hline
\end{tabular}

Note: Organizational Innovative Culture = IGL, Green Recruitment and Selection $=$ GRS, Green Training $=$ GT, Green Compensation $=\mathrm{GC}$, Green Performance assessment = GPA, Firms' Environmental Innovation $=$ FEI

Table 8. Effect size of the study variables

\begin{tabular}{cc}
\hline Constructs & $\mathbf{f}^{2}$ \\
\hline GC & 0.014 \\
GPA & 0.055 \\
GRS & 0.103 \\
GT & 0.075 \\
\hline
\end{tabular}

\section{DISCUSSION AND IMPLICATIONS}

The resource-based view (RBV) theory suggests that organizations are in need to employ human capital strategies to attain competitive advantage. In a rapidly developing world, a firm's environmental innovativeness is considering a vital determining factor for the overall success of any organization. Corporate success and preserving a competitive edge are only possible with effective human resource management practices. Evolving this standpoint, this study examined the role of green HRM practices in supporting an organization to develop environmental innovativeness. Earlier studies focused on the establishment of the direct link between green HRM and the environmental sustainability of manufacturing firms $[45,75]$.

This study empirically confirmed the positive effect of green HRM and firm environmental innovativeness. The findings of the current study are parallel to numerous earlier studies where researchers confirmed a positive link between green recruitment and selection and environmental innovativeness. For example, the findings of this study validated the results of Rawashdeh [76] and Singh, Del Giudice, Chierici and Graziano [7] where they found a positive relationship between green HRM practices such as recruitment of new employees and firm's innovation in terms of environmental sustainability. Moreover, there are similarities between the findings of a recent study directed by where they empirically confirmed that green HRM practices are significantly associated with the firm environmental innovation. Furthermore, the findings of this study are parallel to another recent study conducted by Ahmed, Guo, Qureshi, Raza, Khan and Salam [77].

In Malaysia, lack of innovation is among the key constraints for the success of furniture manufacturing firms. It often happens that medium and large furniture manufacturing firms do not have sufficient capabilities to formulate and execute innovative policies. Human capital is an imperative resource for any firm to prosper innovation policies for environmental 
sustainability within an organization. For this, it is highly recommended that medium and large furniture manufacturing firms in Malaysia should consider green HRM practices as these are found with a strong correlation with the firm's environmental innovativeness. Thus, an organization actively involved in innovation strategies by utilizing its HRM functions is likely to achieve robust environmental success.

\subsection{Theoretical implications}

The phenomena of green HRM and its several practices, and how these practices are related to the firm environmental innovativeness have received substantial research consideration from prior researchers. However, being an emerging research field, there are limited studies in developing countries such as Malaysia to offer empirical evidence. Hence, this research contributed to the literature by broadening and understanding the concept of green HRM practices from the prospect of environmental innovativeness among medium and large manufacturing firms in Malaysia.

The theoretical contributions of the present study are manifold. To advance the RBV theory, this study contributed in terms of understanding and explaining what causes firm environmental innovativeness. Based on the arguments developed through the findings, the study suggests that green HRM practices such as green recruitment and selection, green training, green compensation, and green performance assessment are strategic resources that an organization should leverage to bring environment-related innovation within the firm's process. While applying RBV to the green HRM and environmental innovativeness link, this study proposed that employees in a furniture manufacturing firm are critical resources compare to other resources to execute environmentfriendly technologies [68]. Given this, the framework of this could assist HR managers to understand the green HRM practices with an aim to attract, train, motivate and retain those employees who can assist in achieving the organizational goal of environmental innovativeness.

The theoretical framework for this study offers experimental support through statistical findings for the impact of green HRM practices such as green recruitment and selection, green training, green compensation, and green performance assessment on firm environmental innovativeness in the telecommunication sector and organizational innovative culture as a moderator. These findings confirm past research that has shown a significant relationship between different green HRM practices and the environmental performance of a firm [15, 39, 42, 77]. Previous studies called for more research in order to investigate moderating variables and their impact on the relationship between green HRM and the innovativeness of a firm [6, 14, $15,23]$. The study's findings revealed additional pieces of evidence that organizational innovative culture has a moderating role in the relationship between green training, green compensation, and firm environmental innovativeness in the Malaysian furniture industry. In line with the philosophy of social learning theory, the study embraces the key role of organizational innovative culture to promote environmental innovativeness through green HRM practices.

\subsection{Practical Implications}

In a rapidly developing world, a firm's environmental innovativeness is considering a vital determining factor for the overall success of any organization. Corporate success and preserving a competitive edge is only possible with effective human resource management practices. Green HRM involves undertaking environmentally friendly efforts leading to greater efficiency, lower costs, and improved engagement and retention of employees for the green goals of a firm. Green HR policies are focused on individual and collective green behavior functionality. These policies are developed with an aim to enhance a corporate culture that concerns environmental issues. Green HRM contributes to the environmental conduct of employees in a firm that can bring innovative production processes.

From the practical perspective, the proposed research model may offer a comprehensive understanding for HR managers of furniture manufacturing firms who want to enhance environmental innovativeness. The findings recommend that HR managers in these firms need to substantiate their roles to promote innovation for environmental sustainability. In the era of an environmentally conscious society, HR managers should take initiatives to promote innovativeness by formulating green innovation strategies. However, having innovation strategies is not enough for a significant change in terms of environmental innovativeness. This study, therefore, implies that medium and large manufacturing firms in Malaysia are in need to implement green HRM practices to obtain and maintain environmental innovativeness within their firms.

As environmental issues have become a serious problem of the world, the results of this research contribute to providing an approach on how to save the environment by promoting innovation in firms through green HRM practices. This will serve humanity and the whole planet more effectively in a better way. The main contributors to environmental degradation include industrial companies. Environmentally responsible communities demand that businesses reduce their greenhouse gases as production outputs and begin to save natural resources. The proposed research model offers empirical evidence of the importance of environmental innovativeness and its predictors namely, green recruitment and selection, green training, green compensation, and green performance assessment. While adopting the environmental innovativeness policy, furniture manufacturing firms in Malaysia will reap further benefits for society in terms of reducing the deterioration of their environment, offering more green goods and programs, improving resource efficiencies and economic growth, and enhancing the quality of life.

Apparently, the current and future SME entrepreneurs and large manufacturers are the ones who could benefit the most from the findings of the present study. Simply by being aware of the specific green HRM practices that might positively influence the innovation policy for saving the environment, the entrepreneurs can rationalize and improve their firm sustainability and attain public confidence. The study empirically proved that green HRM practices are essential for the furniture industry in Malaysia to achieve its desired environmental goals. Therefore, the study recommends entrepreneurs become more efficient and effective in terms of innovation in products and processes by utilizing their human capital. These findings, in line with prior literature, suggest that Green HRM as an innovative method has a bright future for all stakeholders. In addition, businesses and practitioners can determine the value of establishing a link between employee engagement and participation in environmental management programs and enhanced corporate environmental performance. Furthermore, the study also suggested these 
firms develop a culture that supports innovation at the workplace.

The research results can also be supportive for corporate consultants and coaches in various boot camps and business parks. Therefore, these experts can be more knowledgeable and able to advise to promote green HRM that managers and owners of furniture manufacturing firms must master and train.

This research has a few important implications for policymakers by understanding the determinants of firm environmental innovativeness has significant economic, social, and political effects. Furniture manufacturing firms are significantly contributing to the overall economic growth of Malaysia as well as helping to minimize unemployment and assisting in the reduction of income inequality. Thus, understanding the predictors of the environmental innovativeness of medium and large furniture manufacturing firms may allow policymakers to formulate new support mechanisms or adjust the existing ones to imply environmental sustainability. Therefore, the Government of Malaysia and policymakers should initiate specific training initiatives for the existing and new furniture manufacturers to signify the role of green HRM.

Last but not least, there are also some implications for academics and researchers. Arguably, the topic of environmental innovativeness in emerging economies still needs extensive research for the generalizability of findings. Thus the framework of this study could certainly be broadened, approached, and investigated from various angles. In order to enrich the idea and improve it for all the stakeholders, all the various aspects can be further investigated. Logically, this indicates several areas of suggested future research.

\subsection{Limitations and future research}

Although this study contributes significantly in elaborating the predictors of firm environmental innovativeness in medium and large manufacturing firms in Malaysia, certain limitations should be considered while interpreting and generalizing the findings. Firstly, the use of non-probability samples is a limitation of this study. The inherent bias in convenience sampling is likely since the sample is not selected randomly.

Secondly, collecting a larger sample size is a challenge in emerging economies. Structural equation modeling is considered a large sample technique [78]. The findings can only be viewed as the representative, as the sample size for the present study is relatively small. Moreover, this study is limited to a furniture manufacturing industry based on a single country such as Malaysia and thus the findings should be interpreted with caution. These limitations recommend future studies focusing on the multi-country study with a larger sample size in different work settings to offer a comparative analysis of green HRM practices and their effect on the firm environmental innovativeness. Also, this has not included the factors of intrinsic motivation. While the current study shows the effects of extrinsic motivation factors, it may serve as a groundwork for further research to contrast intrinsic-extrinsic approaches to GHRM.

\section{REFERENCES}

[1] Gurău, C., Dana, L.P. (2018). Environmentally-driven community entrepreneurship: Mapping the link between natural environment, local community and entrepreneurship. Technological Forecasting and Social Change, 129:

221-231. https://doi.org/10.1016/j.techfore.2017.11.023

[2] Gast, J., Gundolf, K., Cesinger, B. (2017). Doing business in a Green way: A systematic review of the ecological sustainability entrepreneurship literature and future research directions. Journal of Cleaner Production, 147: 44-56.

https://doi.org/10.1016/j.jclepro.2017.01.065

[3] Kianto, A., Sáenz, J., Aramburu, N. (2017). Knowledgebased human resource management practices, intellectual capital and innovation. Journal of Business Research, 81: 11-20. https://doi.org/10.1016/j.jbusres.2017.07.018

[4] Miller, J., Szekely, F. (1995). What is "green"? Environmental Impact Assessment Review, 15(5): 401420. https://doi.org/10.1016/0195-9255(95)00042-D

[5] Shen, J., Dumont, J., Deng, X. (2019). Green Human Resource Management in Chinese Enterprises. Routledge. https://doi.org/10.4324/9780429286971

[6] Jabbour, C.J.C., de Sousa Jabbour, A.B.L. (2016). Green human resource management and Green supply chain management: Linking two emerging agendas. Journal of Cleaner Production, 112: 1824-1833. https://doi.org/10.1016/j.jclepro.2015.01.052

[7] Singh, S.K., Del Giudice, M., Chierici, R., Graziano, D. (2020). Green innovation and environmental performance: The role of Green transformational leadership and Green human resource management. Technological Forecasting and Social Change, 150: 119762. https://doi.org/10.1016/j.techfore.2019.119762

[8] Jakpar, S., Tinggi, M., Siang, T.K., Johari, A., Myint, K. T., Sadique, M. (2017). Working capital management and profitability: Evidence from manufacturing sector in Malaysia. Journal of Business \& Financial Affairs, 6(2): 1-9. https://doi.org/10.4172/2167-0234.1000255

[9] Mokthsim, N., Salleh, K.O. (2014). Malaysia's efforts toward achieving a sustainable development: Issues, challenges and prospects. Procedia-Social and Behavioral Sciences, 120: 299-307. https://doi.org/10.1016/j.sbspro.2014.02.107

[10] World Bank. (2014). World Development Indicator. https://openknowledge.worldbank.org/bitstream/handle/ 10986/18237/9781464801631.pdf, accessed on Mar. 18, 2021.

[11] Hizam-Hanafiah, M., Soomro, M.A. (2021). The situation of technology companies in industry 4.0 and the open innovation. Journal of Open Innovation: Technology, Market, and Complexity, 7(1): 34. https://doi.org/10.3390/joitmc7010034

[12] Saeed, B.B., Afsar, B., Hafeez, S., Khan, I., Tahir, M., Afridi, M.A. (2019). Promoting employee's proenvironmental behavior through green human resource management practices. Corporate Social Responsibility and Environmental Management, 26(2): 424-438. https://doi.org/10.1002/csr.1694

[13] Hameed, Z., Khan, I.U., Islam, T., Sheikh, Z., Naeem, R.M. (2020). Do green HRM practices influence employees' environmental performance? International Journal of Manpower, 41(7): 1061-1079. https://doi.org/10.1108/IJM-08-2019-0407

[14] Ratnasingam, J. (2015). The Malaysian Furniture Industry: Unravelling its Growth and Challenges to 
Innovation. Universiti Putra Malaysia Press. https://pnc.upm.edu.my/upload/dokumen/20181008120 730Prof._Jegatheswaran_(Combine).pdf.

[15] Ratnasingam, J., Ab Latib, H., Yi, L.Y., Liat, L.C., Khoo, A. (2019). Extent of automation and the readiness for Industry 4.0 among Malaysian furniture manufacturers. BioResources, $\quad$ 14(3): 7095-7110. https://ojs.cnr.ncsu.edu/index.php/BioRes/article/view/ BioRes_14_3_7095_Ratnasingam_Automation_Readin ess_Industry_Furniture/7027.

[16] Ng, B.K., Thiruchelvam, K. (2012). The dynamics of innovation in Malaysia's wooden furniture industry: Innovation actors and linkages. Forest Policy and Economics, 14(1): 107-118. https://doi.org/10.1016/j.forpol.2011.08.011

[17] Tajfel, H., Turner, J.C., Austin, W.G., Worchel, S. (1979). An integrative theory of intergroup conflict. Organizational Identity: A Reader, 56(65): 9780203505984-16.

[18] Tumi, N.S., Hasan, A.N., Khalid, J. (2021). Impact of compensation, job enrichment and enlargement, and training on employee motivation. Business Perspectives and Research, 2278533721995353. https://doi.org/10.1177/2278533721995353

[19] Wernerfelt, B. (1984). A resource-based view of the firm. Strategic Management Journal, 5(2): 171-180. https://doi.org/10.1002/smj.4250050207

[20] Barney, J.B. (1991). The resource based view of strategy: Origins, implications, and prospects. Journal of Management, 17(1): 97-211. https://doi.org/10.1177/014920639101700107

[21] Takeuchi, R., Lepak, D.P., Wang, H., Takeuchi, K. (2007). An empirical examination of the mechanisms mediating between high-performance work systems and the performance of Japanese organizations. Journal of $\begin{array}{llll}\text { Applied } & \text { Psychology, } & \text { 92(4): } & 1069 .\end{array}$ https://doi.org/10.1037/0021-9010.92.4.1069

[22] Paillé, P., Chen, Y., Boiral, O., Jin, J. (2014). The impact of human resource management on environmental performance: An employee-level study. Journal of Business $\quad$ Ethics, 121(3): 451-466. https://doi.org/10.1007/s10551-013-1732-0

[23] Cooperman, E.S., Brost, E.R. (2011). Measuring costs and benefits. A Simple Path to Sustainability, 14.

[24] Wright, P.M., Dunford, B.B., Snell, S.A. (2001). Human resources and the resource based view of the firm. Journal of management, 27(6): 701-721. https://doi.org/10.1177/014920630102700607

[25] Whitfield, K. (2019). The Resource-Based View approach and HRM. In Elgar Introduction to Theories of Human Resources and Employment Relations. Edward Elgar https://doi.org/10.4337/9781786439017.00030

[26] Chesbrough, H., Lettl, C., Ritter, T. (2018). Value creation and value capture in open innovation. Journal of Product Innovation Management, 35(6): 930-938. https://doi.org/10.1111/jpim.12471

[27] Akers, R.L., Jennings, W.G. (2016). Social learning theory. Wiley Handbooks in Criminology and Criminal Justice, 230-240. https://doi.org/10.1002/9781118512449.ch12

[28] Khalid, J., Nordin, N.M., Ali, A.J., Iftikhar, U., Jamil, A. (2020). Exploring factors influencing student study abroad choice of destination in the contemporary globalized era (Kajian Tentang Faktor-faktor yang Mempengaruhi Pemilihan Destinasi Pelajar Luar Negara dalam Era Kontemporari Globalisasi). Akademika, 90(2). https://doi.org/10.17576/akad-2020-90IK2-02

[29] Jackson, S.E., Seo, J. (2010). The Greening of strategic HRM scholarship. Organization Management Journal, 7(4): 278-290. https://doi.org/10.1057/omj.2010.37

[30] LaRose, R., Whitten, P. (2000). Re-thinking instructional immediacy for web courses: A social cognitive exploration. Communication Education, 49(4): 320-338. https://doi.org/10.1080/03634520009379221

[31] Bandura, A. (1985). Model of causality in social learning theory. In Cognition and Psychotherapy, pp. 81-99. Springer, Boston, MA. https://doi.org/10.1007/978-14684-7562-3_3

[32] De Vries, H., Bekkers, V., Tummers, L. (2016). Innovation in the public sector: A systematic review and future research agenda. Public Administration, 94(1); 146-166. https://doi.org/10.1111/padm.12209

[33] Demirel, P., Kesidou, E. (2019). Sustainability-oriented capabilities for eco-innovation: Meeting the regulatory, technology, and market demands. Business Strategy and the Environment, 28(5): 847-857. https://doi.org/10.1002/bse.2286

[34] Angelo, F.D., Jabbour, C.J.C., Galina, S.V.R. (2012). Environmental Innovation: in search of a meaning. World Journal of Entrepreneurship, Management and Sustainable Development, pp. 113-121. https://doi.org/10.1108/20425961211247734

[35] Díaz-García, C., González-Moreno, Á., Sáez-Martínez, F.J. (2015). Eco-innovation: insights from a literature review. Innovation, 6-23. https://doi.org/10.1080/14479338.2015.1011060

[36] Kemp, R., Pearson, P. (2007). Final report MEI project about measuring eco-innovation. UM Merit, Maastricht, 10: 2. https://www.oecd.org/env/consumptioninnovation/43960830.pdf.

[37] Bocken, N.M., Geradts, T.H. (2020). Barriers and drivers to sustainable business model innovation: Organization design and dynamic capabilities. Long Range Planning, 53(4): 101950. https://doi.org/10.1016/j.lrp.2019.101950

[38] Guerci, M., Longoni, A., Luzzini, D. (2016). Translating stakeholder pressures into environmental performancethe mediating role of Green HRM practices. The International Journal of Human Resource Management, 27(2): https://doi.org/10.1080/09585192.2015.1065431

[39] Mishra, R.K., Sarkar, S., Kiranmai, J. (2014). Green HRM: innovative approach in Indian public enterprises. World Review of Science, Technology and Sustainable Development, $11(1)$ 26-42. https://www.inderscienceonline.com/doi/pdf/10.1504/W RSTSD.2014.062374.

[40] Diana, G.C., Jabbour, C.J.C., de Sousa Jabbour, A.B.L., Kannan, D. (2017). Putting environmental technologies into the mainstream: Adoption of environmental technologies by medium-sized manufacturing firms in Brazil. Journal of Cleaner Production, 142: 4011-4018. https://doi.org/10.1016/j.jclepro.2016.10.054

[41] O'Donohue, W., Torugsa, N. (2016). The moderating effect of 'Green'HRM on the association between proactive environmental management and financial performance in small firms. The International Journal of 
Human Resource Management, 27(2): 239-261. https://doi.org/10.1080/09585192.2015.1063078

[42] Wagner, M. (2013). 'Green' human resource benefits: do they matter as determinants of environmental management system implementation? Journal of Business $\quad$ Ethics, 114(3): 443-456. https://doi.org/10.1007/s10551-012-1356-9

[43] Jabbour, C.J.C. (2011). How Green are HRM practices, organizational culture, learning and teamwork? A Brazilian study. Industrial and Commercial Training, 43(2):

98-105. https://doi.org/10.1108/00197851111108926

[44] Nejati, M., Rabiei, S., Jabbour, C.J.C. (2017). Envisioning the invisible: Understanding the synergy between Green human resource management and green supply chain management in manufacturing firms in Iran in light of the moderating effect of employees' resistance to change. Journal of Cleaner Production, 168: 163-172. https://doi.org/10.1016/j.jclepro.2017.08.213

[45] Yusliza, M.Y., Othman, N.Z., Jabbour, C.J.C. (2017). Deciphering the implementation of Green human resource management in an emerging economy. Journal of Management Development, 36(10): 1230-1246. https://doi.org/10.1108/JMD-01-2017-0027

[46] Sadhu, S.D., Garg, M., Kumar, A. (2018). Major environmental issues and new materials. In New Polymer Nanocomposites for Environmental Remediation, pp. 77-97. https://doi.org/10.1016/B978-0-12-8110331.00004-4

[47] Nisar, Q.A., Haider, S., Ali, F., Jamshed, S., Ryu, K., Gill, S.S. (2021). Green human resource management practices and environmental performance in Malaysian green hotels: The role of green intellectual capital and pro-environmental behavior. Journal of Cleaner Production, 311: 127504. https://doi.org/10.1016/j.jclepro.2021.127504

[48] Renwick, D.W.S., Jabbour, C.J.C., Muller-Camen, M., Redman, T., Wilkinson, A. (2016). Contemporary developments in Green (environmental) HRM scholarship. The International Journal of Human Resource Management, 27(2): 114-128.

[49] Kim, Y.J., Kim, W.G., Choi, H.M., Phetvaroon, K. (2019). The effect of green human resource management on hotel employees' eco-friendly behavior and environmental performance. International Journal of Hospitality Management, 76: 83-93.

[50] Luu, T.T. (2018). Employees' green recovery performance: the roles of green HR practices and serving culture. Journal of Sustainable Tourism, 26(8): 13081324. https://doi.org/10.1080/09669582.2018.1443113

[51] Renwick, D.W., Redman, T., Maguire, S. (2013). Green human resource management: A review and research agenda. International Journal of Management Reviews, 15(1): $\quad 1-14 . \quad$ https://doi.org/10.1111/j.14682370.2011.00328.x

[52] El-Kassar, A.N., Singh, S.K. (2019). Green innovation and organizational performance: the influence of big data and the moderating role of management commitment and HR practices. Technological Forecasting and Social Change, 144: 483-498. https://doi.org/10.1016/j.techfore.2017.12.016

[53] Seeck, H., Diehl, M.R. (2017). A literature review on HRM and innovation-taking stock and future directions. The International Journal of Human Resource
Management, 28(6): 913-944. https://doi.org/10.1080/09585192.2016.1143862

[54] Škerlavaj, M., Song, J.H., Lee, Y. (2010). Organizational learning culture, innovative culture and innovations in South Korean firms. Expert Systems with Applications, 37(9): 6390-6403. https://doi.org/10.1016/j.eswa.2010.02.080

[55] Ott, J.S. (1989). The Organizational Culture Perspective. Dorsey Press.

[56] Parker, M. (2000). Organizational culture and identity: Unity and Division at Work. Sage. http://dx.doi.org/10.4135/9781446217214.n3

[57] Alvesson, M. (2012). Understanding organizational culture. Sage.

[58] Peters, T.J., Waterman, R.H. (1982). In search of excellence: Lessons from America's best-run companies, NASSP, 67(466): https://doi.org/10.1177/019263658306746628

[59] Lau, C.M., Ngo, H.Y. (1996). One country many cultures: Organizational cultures of firms of different country origins. International Business Review, 5(5): 469-486. https://doi.org/10.1016/0969-5931(96)00022-4

[60] Wiener, Y. (1988). Forms of value systems: Focus on organizational effectiveness and cultural change and maintenance. Academy of Management Review, 13(4): 534-545. https://doi.org/10.5465/amr.1988.4307410

[61] Lukoto, K., Chan, K.Y. (2016). The perception of innovative organisational culture and its influence on employee innovative work behaviour. In 2016 Portland International Conference on Management of Engineering and Technology (PICMET), pp. 972-977. https://doi.org/10.1108/IJPSM-01-2021-0005

[62] Kandemir, D., Hult, G.T.M. (2005). A conceptualization of an organizational learning culture in international joint ventures. Industrial Marketing Management, 34(5): 430439. https://doi.org/10.1016/j.indmarman.2004.10.002

[63] Sharifirad, M.S., Ataei, V. (2012). Organizational culture and innovation culture: Exploring the relationships between constructs. Leadership \& Organization Development Journal, 33(5): 494-517. https://doi.org/10.1108/01437731211241274

[64] Upadhyay, P., Kumar, A. (2020). The intermediating role of organizational culture and internal analytical knowledge between the capability of big data analytics and a firm's performance. International Journal of Information Management, 52: 102100.

[65] Prajogo, D.I., McDermott, C.M. (2005). The relationship between total quality management practices and organizational culture. International Journal of Operations \& Production Management.

[66] Cohen, W.M., Levinthal, D.A. (1990). Absorptive capacity: A new perspective on learning and innovation. Administrative Science Quarterly, 128-152.

[67] Nonaka, I., Kodama, M., Hirose, A., Kohlbacher, F. (2014). Dynamic fractal organizations for promoting knowledge-based transformation-A new paradigm for organizational theory. European Management Journal, 32(1): 137-146.

[68] Ratnasingam, J., Khoo, A., Jegathesan, N., et al. (2020). How are small and medium enterprises in Malaysia's furniture industry coping with COVID-19 pandemic? Early evidences from a survey and recommendations for policymakers. BioResources, 15(3): 5951-5964. https://ojs.cnr.ncsu.edu/index.php/BioRes/article/view/ 
BioRes_15_1_5951_Ratnasingam_Small_Medium_Ent erprises_Malaysia.

[69] Mousa, S.K., Othman, M. (2020). The impact of green human resource management practices on sustainable performance in healthcare organisations: A conceptual framework. Journal of Cleaner Production, 243: 118595. https://doi.org/10.1016/j.jclepro.2019.118595

[70] Masri, H.A., Jaaron, A.A. (2017). Assessing green human resources management practices in Palestinian manufacturing context: An empirical study. Journal of Cleaner Production, 143: 474-489. https://doi.org/10.1016/j.jclepro.2016.12.087

[71] Martinez-Conesa, I., Soto-Acosta, P., Carayannis, E.G. (2017). On the path towards open innovation: Assessing the role of knowledge management capability and environmental dynamism in SMEs. Journal of Knowledge Management, 1(3): 553-570. https://doi.org/10.1108/JKM-09-2016-0403

[72] Podsakoff, P.M., Organ, D.W. (1986). Self-reports in organizational research: Problems and prospects. Journal of Management, 12: 531-544 https://doi.org/10.1177/014920638601200408

[73] HAIR, J.J.F., Sarstedt, M., Hopkins, L., Kuppelwieser, V.G. (2014). Partial least squares structural equation modeling (PLS-SEM): An emerging tool in business research. European Business Review, 26: 106-121. https://doi.org/10.1108/EBR-10-2013-0128

[74] Sullivan, G.M., Feinn, R. (2012). Using effect size-or why the $p$ value is not enough. Journal of Graduate Medical Education, 4: 279-282. https://doi.org/10.4300/JGME-D-12-00156.1

[75] Cohen, J. (1988). Statistical power analysis for the behavioral sciences, 2nd ed. Hillsdale, NJ: Erlbaum. https://doi.org/10.4324/9780203771587

[76] Rawashdeh, A. (2018). The impact of Green human resource management on organizational environmental performance in Jordanian health service organizations. Management Science Letters, 8(10): 1049-1058. https://doi.org/10.5267/j.msl.2018.7.006

[77] Ahmed, M., Guo, Q., Qureshi, M.A., Raza, S.A., Khan, K.A., Salam, J. (2021). Do green HR practices enhance green motivation and proactive environmental management maturity in hotel industry? International Journal of Hospitality Management, 94: 102852. https://doi.org/10.1016/j.ijhm.2020.102852

[78] Kline, R.B. (2011). Methodology in the Social Sciences. Principles and Practice of Structural Equation Modeling (3rd ed.). Guilford Press. https://www.scirp.org/(S(351jmbntvnsjt1 aadkozje))/refe rence/referencespapers.aspx ?referenceid $=1375492$. 